\title{
Superhydrophobic poly(L-lactic acid) surface as potential bacterial colonization substrate
}

\author{
Cláudia Sousa $^{1 \dagger}$, Diana Rodrigues ${ }^{1 \dagger}$, Rosário Oliveira ${ }^{1}$, Wenlong Song ${ }^{1,2,3}$, João F Mano ${ }^{1,2,3}$ and Joana Azeredo ${ }^{{ }^{*}}$
}

\begin{abstract}
Hydrophobicity is a very important surface property and there is a growing interest in the production and characterization of superhydrophobic surfaces. Accordingly, it was recently shown how to obtain a superhydrophobic surface using a simple and cost-effective method on a polymer named poly(L-lactic acid) (PLLA). To evaluate the ability of such material as a substrate for bacterial colonization, this work assessed the capability of different bacteria to colonize a biomimetic rough superhydrophobic (SH) PLLA surface and also a smooth hydrophobic $(\mathrm{H})$ one. The interaction between these surfaces and bacteria with different morphologies and cell walls was studied using one strain of Staphylococcus aureus and one of Pseudomonas aeruginosa. Results showed that both bacterial strains colonized the surfaces tested, although significantly higher numbers of $S$. aureus cells were found on SH surfaces comparing to $\mathrm{H}$ ones. Moreover, scanning electron microscopy images showed an extracellular matrix produced by P. aeruginosa on SH PLLA surfaces, indicating that this bacterium is able to form a biofilm on such substratum. Bacterial removal through lotus leaf effect was also tested, being more efficient on $\mathrm{H}$ coupons than on SH PLLA ones. Overall, the results showed that SH PLLA surfaces can be used as a substrate for bacterial colonization and, thus, have an exceptional potential for biotechnology applications.
\end{abstract}

Keywords: Poly(L-lactic acid), Superhydrophobicity, Biomimetic surfaces, Bacterial colonization substrate

\section{Introduction}

Industrial bioconversion processes can be performed using different kinds of reactors, some of which are called "immobilized cell reactors", (Tyagi and Ghose 1982) that imply high cell concentrations, normally achieved by fixing the cells on various substrates. Adsorption is one of the different techniques used to immobilize microbial cells, rendering the immobilization process more economic and the reactors simpler in concept and construction. In fact, it is a natural immobilization process, since cells adsorb and adhere to the support naturally and firmly (Tyagi and Ghose 1982; Forberg and Haggstrom 1985; Qureshi and Maddox 1987), eventually developing into biofilms. On the other hand, surface has an important impact on bacterial colonization and several different materials have been used as substrata for cell immobilization, such as rocks,

\footnotetext{
*Correspondence: jazeredo@deb.uminho.pt

+ Contributed equally

${ }^{1}$ Institute for Biotechnology and Bioengineering, Centre of Biological Engineering, University of Minho, Campus de Gualtar, 4710-057 Braga, Portugal

Full list of author information is available at the end of the article
}

sands, latex, and steel. There are several criteria used to characterize a good substratum, and surface characteristics suitable for bacterial attachment must definitely be taken into consideration. Among surface physicochemical properties, hydrophobicity has been considered one of the most important, since in biological systems hydrophobic interactions are the strongest long-range non-covalent interactions, being considered a determining factor in microbial adhesion to surfaces (Sanin et al. 2003). Moreover, it has been shown that biofilm formation tends to increase with the hydrophobicity of the surface material (Donlan and Costerton 2002).

Since artificial superhydrophobic surfaces were first demonstrated in the mid-1990s (Onda et al. 1996), a very large number of inventive ways to produce rough surfaces that exhibit superhydrophobicity have been reported. Accordingly, a great deal of research has been devoted to the preparation and theoretical modelling of superhydrophobic surfaces (Nakajima et al. 2001; Callies and Quéré 2005; Parkin and Palgrave 2005; Sun et al. 2005), which result from the combination of a very large contact angle $\left(\geq 150^{\circ}\right)$ and a low contact-angle 
hysteresis. This kind of materials was originally inspired by the unique water-repellent properties of the lotus leaf (Barthlott and Neinhuis 1997) and the leaves of a number of other plants (Bhushan and Jung 2006). The so called "lotus effect", the superhydrophobicity of the surface, is the result of specific surface features on the lotus leaf: small nano-sized "bumps" make the contact surface area between the droplet and the leaf extremely small. This minimizes the attractive forces between the water molecules and the atoms of the surface, and allows the water to "bead up" and rolls off (Frim 2008).

Various methods have been proposed to fabricate superhydrophobic surfaces, such as the solution method (Erbil et al. 2003; Xie et al. 2004; Shi et al. 2008; Oliveira et al. 2010), the sol-gel method (Tadanaga et al. 2000; Shirtcliffe et al. 2003; Wang et al. 2005), solidification of alkylketene dimer (Onda et al. 1996), the plasma fluorination method (Teare et al. 2002; Woodward et al. 2003), among others (Bico et al. 1999; Nakajima et al. 1999; Genzer and Efimenko 2000; Nakajima et al, 2000). Poly(L-lactic acid) (PLLA) is a biodegradable polymer that has been used to produce superhydrophobic surfaces and has received substantial attention, not only due to its renewable resources (Tsuji et al. 1998) but also because of its biocompatibility, as well as excellent thermal and mechanical properties, and superior transparency of the processed materials (Urayama et al. 2002). In fact, biodegradable polymers have been receiving an increasing interest for biomedical applications, given that biodegradable polymeric films have potential applications for cell growth substrata, tissue engineering and drug delivery. In this context, Song et al. (2009) developed recently robust hydrophobic $(\mathrm{H})$ and superhydrophobic (SH) PLLA substrates using a simple, cost-effective, and novel method. They have also studied the colonization of those materials by animal cells (mouse lung line L929) after different surface treatments. These authors observed that almost no animal cell adhesion occurred on the SH PLLA surfaces in comparison with the smooth $(\mathrm{H})$ ones, and that the enhancement in hydrophilicity resulting from Ar-plasma treatment may greatly improve animal cell attachment. Similar behaviour was found with bone marrow derived cells on such kind of substrates (Alves et al. 2009). However, to our knowledge, there are no reports regarding bacterial interaction with such surfaces. Therefore, the present work aimed at studying the microbial colonization of $\mathrm{H}$ and SH PLLA surfaces by different kinds of bacteria and, consequently, evaluating the potential application of these materials as substrates in the biotechnological field when high levels of immobilized biomass are required.

\section{Materials and methods}

\section{Poly(L-lactic) surfaces}

The methodology used to obtain $\mathrm{H}$ and SH PLLA surfaces was the same previously described by Song et al. (2009). Briefly, a commercially available PLLA of high stereoregularity (Cargill Dow Polymer Mn = 69 000, $\mathrm{M}_{\mathrm{w}} / \mathrm{M}_{\mathrm{n}}=1.734$ ) was converted to a flat rigid smooth PLLA substrate by melting the PLLA powder over a glass slide, compression with another glass slide, and further cooling in water. On the other hand, the rough $\mathrm{SH}$ surface was obtained using a PLLA/dioxane 13\% (w/ w) solution that was cast on the previous (smooth) substrate. The surface morphology of both kinds of PPLA surfaces was assessed through scanning electron microscopy (SEM), while the roughness of the superhydrophobic PLLA substrate was assessed using a NT1100Optical Profiler.

Round shaped coupons with $2.5 \mathrm{~mm}$ in diameter of each type of PLLA surfaces were used to assess bacterial adhesion. The coupons were previously cleaned by immersion in a $70 \%$ ethanol solution, and then aseptically and individually washed with ultra-pure sterile water and let to dry overnight at room temperature $\left(21^{\circ}\right.$ C).

\section{Bacterial strains and culture conditions}

In order to assess the interaction between the distinct PLLA surfaces with different bacterial cell walls, this work included the Gram-positive Staphylococcus aureus CECT 239 (CECT, Colección Española de Cultivos Tipo), and the Gram-negative Pseudomonas aeruginosa ATCC 10145 (ATCC, American Type Collection Culture).

For each experiment, bacteria were subcultured on tryptic soy agar (TSA, Merck, Darmstadt, Germany) for about $36 \mathrm{~h}$ at $37^{\circ} \mathrm{C}$ and then grown for $24 \mathrm{~h}$ in $15 \mathrm{~mL}$ of tryptic soy broth (TSB, Merck), at $37^{\circ} \mathrm{C}$ under a constant agitation of $120 \mathrm{rpm}$ (SI50; Stuart Scientific, Redhill, UK). After this period, an aliquot of $50 \mu \mathrm{L}$ of the culture suspension was transferred into $30 \mathrm{~mL}$ of fresh TSB and incubated for $18 \mathrm{~h}$ under the same conditions in order to obtain a midexponential growth culture. Cells were harvested by centrifugation at $9000 \mathrm{rpm}$ at $4^{\circ}$ $\mathrm{C}$ for 5 minutes (3-16 K, Laborzentrifugen $\mathrm{GmbH}$, Osterode, Germany) and washed twice with a saline solution $[0.9 \% \mathrm{NaCl}(\mathrm{w} / \mathrm{v})$ (Merck) in sterile distilled water]. The cellular suspensions were adjusted to a final concentration of $1 \times 10^{8}$ cells per $\mathrm{mL}$, determined by optical density at $640 \mathrm{~nm}$, prior to subsequent assays.

\section{Surface colonization and cell enumeration}

In order to promote bacterial colonization, each clean coupon of $\mathrm{H}$ and SH PLLA surfaces was placed into an 
individual well of a 24-well microtiter plate containing $1.5 \mathrm{~mL}$ of TSB enriched with $0.25 \%$ of glucose (Merck). For each bacterium, a $50 \mu \mathrm{L} 1 \times 10^{8}$ cells $/ \mathrm{mL}$ inoculum was added per well. The plates were incubated for $24 \mathrm{~h}$ at $37^{\circ} \mathrm{C}$ in an orbital shaker $(120 \mathrm{rpm})$. All experiments were performed in triplicate, in three independent occasions.

After the incubation period, the number of bacterial cells colonizing the surfaces was determined by colony forming units (CFU) enumeration. In order to do so, coupons were transferred to a new 24-well microtiter plate and carefully washed twice with $\mathrm{NaCl} 0.9 \%$. For each bacterium and material tested, four coupons were placed in a sterile eppendorf containing $1 \mathrm{~mL}$ of $\mathrm{NaCl}$ $0.9 \%$ and vortexed vigorously for 2 minutes. Next, the content of each eppendorf was sonicated twice $(20 \mathrm{~s}$, $22 \%$ of amplitude) (Ultrasonic Processor, Cole-Parmer, Illinois, USA) in order to detach the cells from the coupons. The remaining suspension was centrifuged $(5 \mathrm{~min}$, $9000 \mathrm{rpm}, 4^{\circ} \mathrm{C}$ ) and resuspended in $1 \mathrm{~mL}$ of $\mathrm{NaCl} 0.9 \%$. Viable cells were determined by performing 10-fold serial dilutions in saline solution $(\mathrm{NaCl} 0.9 \%)$ and plated in TSA, in triplicate. Prior to colony enumeration, the plates were incubated for $24 \mathrm{~h}$ at $37^{\circ} \mathrm{C}$.

\section{Bacteria removal assays}

Bacteria removal assays were performed to assess the "self-cleaning" character of both kinds of PLLA surfaces. For that, the same experimental procedure described for the colonization assays (section 2.3) was used, except that, before transferring to eppendorfs for sonication, each coupon was gently immersed in ultrapure sterile water and then tilted to allow the liquid to flow over the surface. The remaining cells were collected and enumerated as described in section 2.3.

\section{Scanning Electron Microscopy (SEM)}

In order to observe how the different bacterial cells were distributed on the surface of both kinds of PLLA surfaces, coupons representing each experimental condition were visualized under a scanning electron microscope. Therefore, after the $24 \mathrm{~h}$ incubation period, coupons were dehydrated by a 15 min immersion in solutions with increasing concentrations of ethanol up to $100 \%$ ( $\mathrm{vol} / \mathrm{vol}$ ), having then been placed in a sealed desiccator. Morphological analysis was performed in an Ultra-high resolution Field Emission Gun Scanning Electron Microscopy (FEG-SEM), NOVA 200 Nano SEM, FEI Company. Secondary electron images were performed with an acceleration voltage of between 5 e $10 \mathrm{KV}$. Before morphological analyses, the samples were covered with a very thin film of Au-Pd (80-20 weight \%) with $8 \mathrm{~nm}$ thickness, in a high resolution sputter coater, $208 \mathrm{HR}$ Cressington Company.

\section{Statistical analysis}

Data analysis was performed using the statistical program SPSS (Statistical Package for the Social Sciences). The results were compared using the non-parametric Mann-Whitney U-test at a 95\% confidence level.

\section{Results}

\section{Quantification of bacterial colonization and removal}

As can be seen in Figure 1, the enumeration of $S$. aureus and $P$. aeruginosa cells showed that both bacteria extensively colonized both PLLA surfaces, achieving values of 4 Log CFUs $/ \mathrm{cm}^{2}$. Nevertheless, a significant higher amount of $S$. aureus cells was found on the $\mathrm{SH}$ surface comparing to the $\mathrm{H}$ one. Regarding $\mathrm{H}$ surface colonization by both bacteria, a significant greater amount of $P$. aeruginosa cells was found comparing to $S$. aureus (Figure 1).

As far as removal assays are concerned, it was observed that both bacteria did not suffer a significant decrease of biomass amount on the $\mathrm{SH}$ surface (Figure 1 ). In contrast, the removal was more effective on the $\mathrm{H}$ surface, since both bacteria suffered a significant reduction ( 1 Log reduction) on the number of cells adhered to this substratum comparing to the values found when no removal procedure was performed.

\section{Surface morphology and roughness and spatial distribution of bacterial cells}

SEM images, presented in Figure 2, show the contrasting morphologies of both surfaces tested, confirming that the $\mathrm{H}$ surface is much smoother (Figure 2a) than the $\mathrm{SH}$ surface, which is fully covered with papilla-like protrusions (Figures $2 \mathrm{~b}$ and $2 \mathrm{c}$ ) with sizes of about 10 $\mu \mathrm{m}$. Such rough structure was also seen by optical profilometry (Figure 3 ) that indicated an average roughness of $8.28 \mu \mathrm{m}$ and a diameter of each papillae of $8.97 \mu \mathrm{m}$, which is consistent with the size of such structures seen by SEM. It was also observed that, unlike $P$. aeruginosa cells, $S$. aureus cells seem to fit perfectly the holes and recesses on the $\mathrm{SH}$ surface (Figures $4 \mathrm{a}$ and $4 \mathrm{~b}$ ). Moreover, in contrast to what was observed for S. aureus, SEM images revealed that $P$. aeruginosa was able to produce biofilm on the $\mathrm{SH}$ surface, showing the presence of an extracellular matrix that, together with the cells, covered most of the rough surface (Figure 4c).

It is also important to note that the hydrophobicity of the same materials used in the present work had been previously assessed by contact angle (CA) measurements that showed a significant difference between both types of surfaces, with a CA mean value of $70^{\circ}$ for the smooth $\mathrm{H}$ surface and $154^{\circ}$ for the rough SH surface (Song et al. 2009).

\section{Discussion}

Together with extracellular polymers and surface electrostatic charge, hydrophobicity is, undoubtedly, one of 


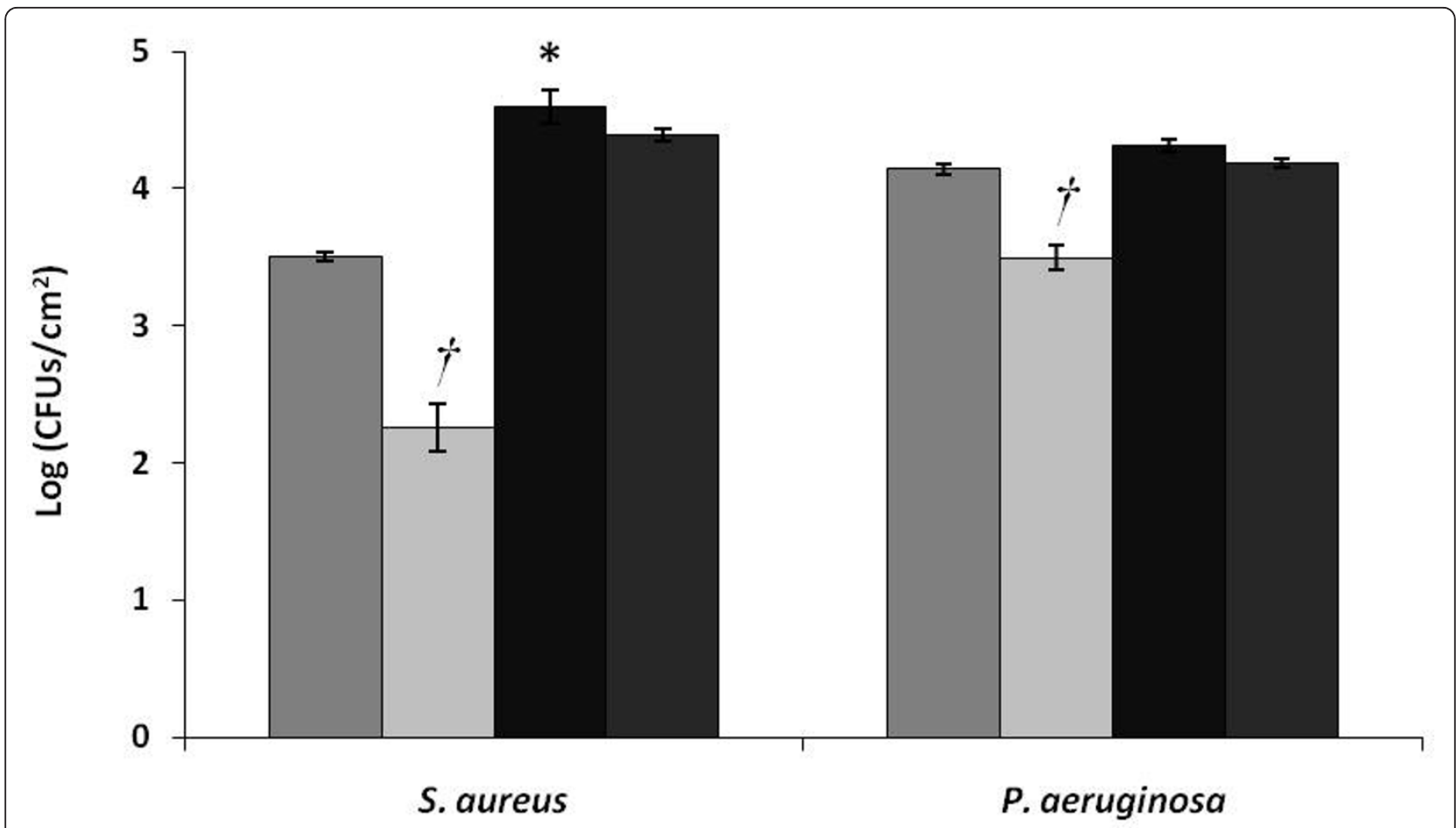

$\square$ Hydrophobic without removal

Superhydrophobic without removal $\square$ Hydrophobic with removal

- Superhydrophobic with removal

Figure 1 Number of $S$. aureus and $P$. aeruginosa cells, per square centimetre of SH PLLA and H PLLA surfaces, after colonization and removal assays. Symbols indicate statistically different values $(p<0.05)$ between colonization of both kinds of surface considering the same bacteria $\left(^{*}\right)$, and between the amount of cells present on a same surface before and after the removal procedure $(t)$.

the critical surface properties (Gannon et al. 1991; Ahn and Lee 2003) since hydrophobic interactions define the strong attraction between hydrophobic molecules and surfaces in water. In biological systems, hydrophobic interactions are the strongest long-range non-covalent interactions and are considered a determining factor in microbial adhesion to surfaces (Sanin et al. 2003). Given the hydrophobic nature of the surfaces tested in the present study, the results obtained are in agreement with previous works, which show that $S$. aureus and $P$. aeruginosa preferentially colonize hydrophobic surfaces than hydrophilic ones (Ajayi et al. 2010; Zmantar et al. 2011). On the other hand, previous studies performed with the same SH surface used in the present work had demonstrated that almost no animal cell adhesion occurred (Alves et al. 2009; Song et al. 2009). These contrasting findings might be related with the accentuate differences between eukaryotic and prokaryotic cell walls, both in terms of morphology, length and surface properties. For instance, bacterial cells are about one tenth the size of animal cells, which enables them to fit into $\mathrm{SH}$ surface irregularities, while animal cells do not benefit from such a high contact surface. This is probably due to the fact that a rough surface has a greater surface area and the depressions in the roughened surfaces provide more favourable sites for colonization. Grooves or scratches that are in the order of bacterial size increase the contact area and hence the binding potential, whereas grooves that are much larger-wider than the bacterial size approach the binding potential of a flat surface. On the other hand, grooves or scratches too small for the bacterium to fit in them reduce the contact area of the bacterium and hence the binding ability (Edwards and Rutenberg 2001). The significant differences found regarding colonization of both surfaces by $S$. aureus (Figure 1) can be due to the combined effect of the different PLLA and S. aureus specific surface morphologies, since $S$. aureus cells seem to fit perfectly the irregularities on the SH surface (Figures $4 \mathrm{a}$ and $4 \mathrm{~b}$ ) and, thus, end up having a greater contact area than on the smooth $\mathrm{H}$ surface.

Concerning the colonization of the $H$ surface, the significant differences found between bacterial strains (Figure 1) can be related with their distinct cell walls and 


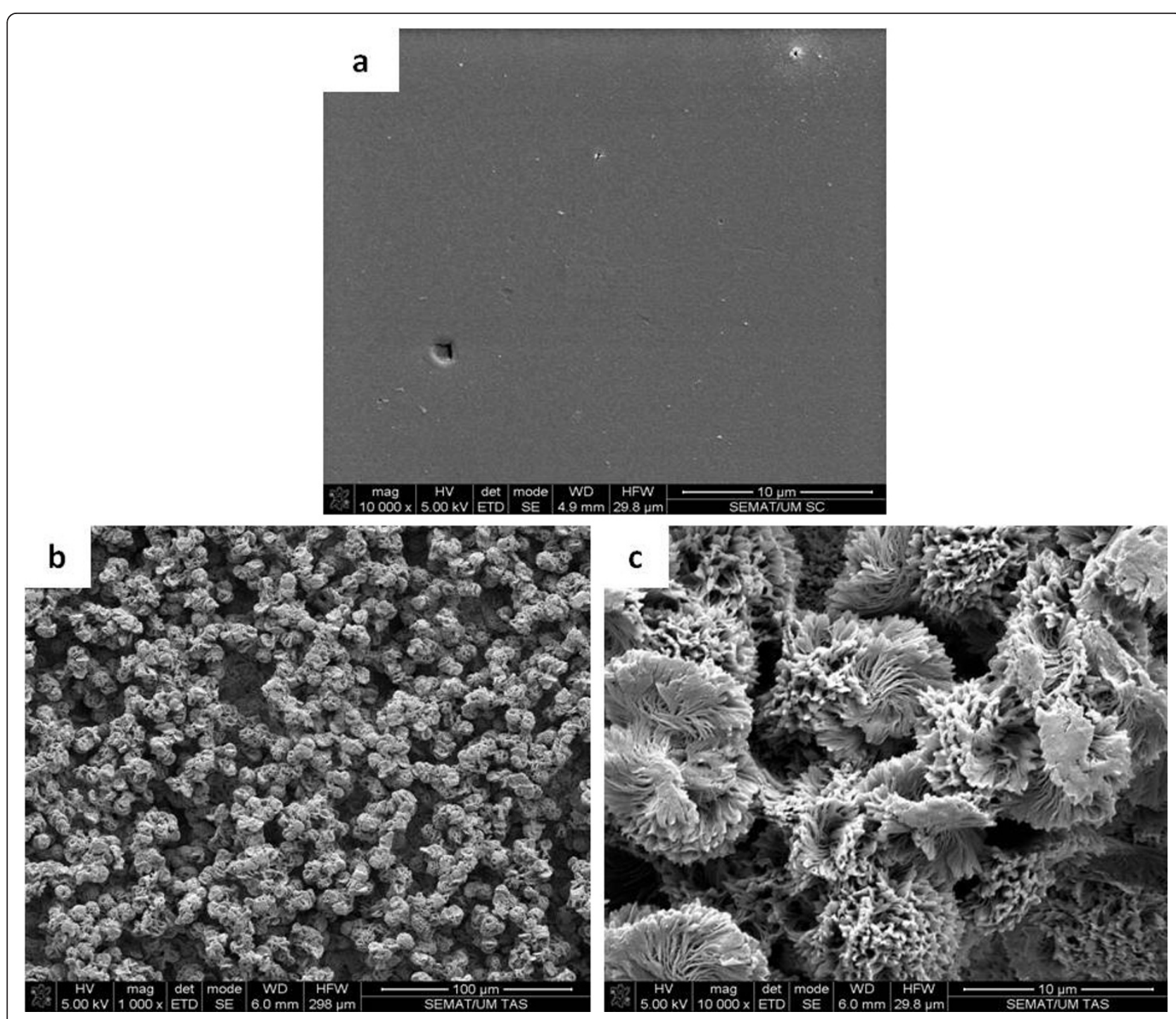

Figure 2 SEM images of (a) the smooth surface of the H PLLA, (b) the rough surface of SH PLLA, and (c) the protrusions on the SH PLLA surface.

extracellular polymeric substances (EPS). In fact, as a Gram-negative bacterium, the cell wall of $P$. aeruginosa contains lipids, proteins, and lipopolysaccharides (LPS), while the cell wall of the Gram-positive bacteria, such as S. aureus, does not contain LPS (Speranza et al. 2004). The LPS of $P$. aeruginosa are the major component of the outer surface, and are a well-established virulence factor (Fletcher et al. 1993; Rocchetta et al. 1999; Thuruthyil et al 2001), contributing to bacterial adhesion (Camesano and Logan 2000), most likely due to nonspecific physiochemical interactions such as hydrophobicity (Thuruthyil et al. 2001). In this way, it is very likely that LPS present in P. aeruginosa cell wall are a determining factor in the colonization of the $\mathrm{H}$ surface, leading to a significant higher amount of cells in detriment to $S$. aureus (Figure 1). It is also described that the adhesion ability of $P$. aeruginosa is associated with the extensive production of EPS (Dunne 2002; Drenkard 2003). Thus, the high amount of EPS produced by $P$. aeruginosa might be responsible for biofilm formation on the SH surface (Figure $4 \mathrm{~d}$ ).

The results of the removal assays are in agreement with those found for the colonization assays, since a significant decrease of biomass of both bacterial strains was only found on the SH surface (Figure 1), suggesting, once again, that the distinct characteristics of both surfaces tested must be responsible for such outcomes. Thus, it is possible to infer that the crevices of the $\mathrm{SH}$ surface not only offer an increased area for attachment by providing more contact points, but also afford protection against 


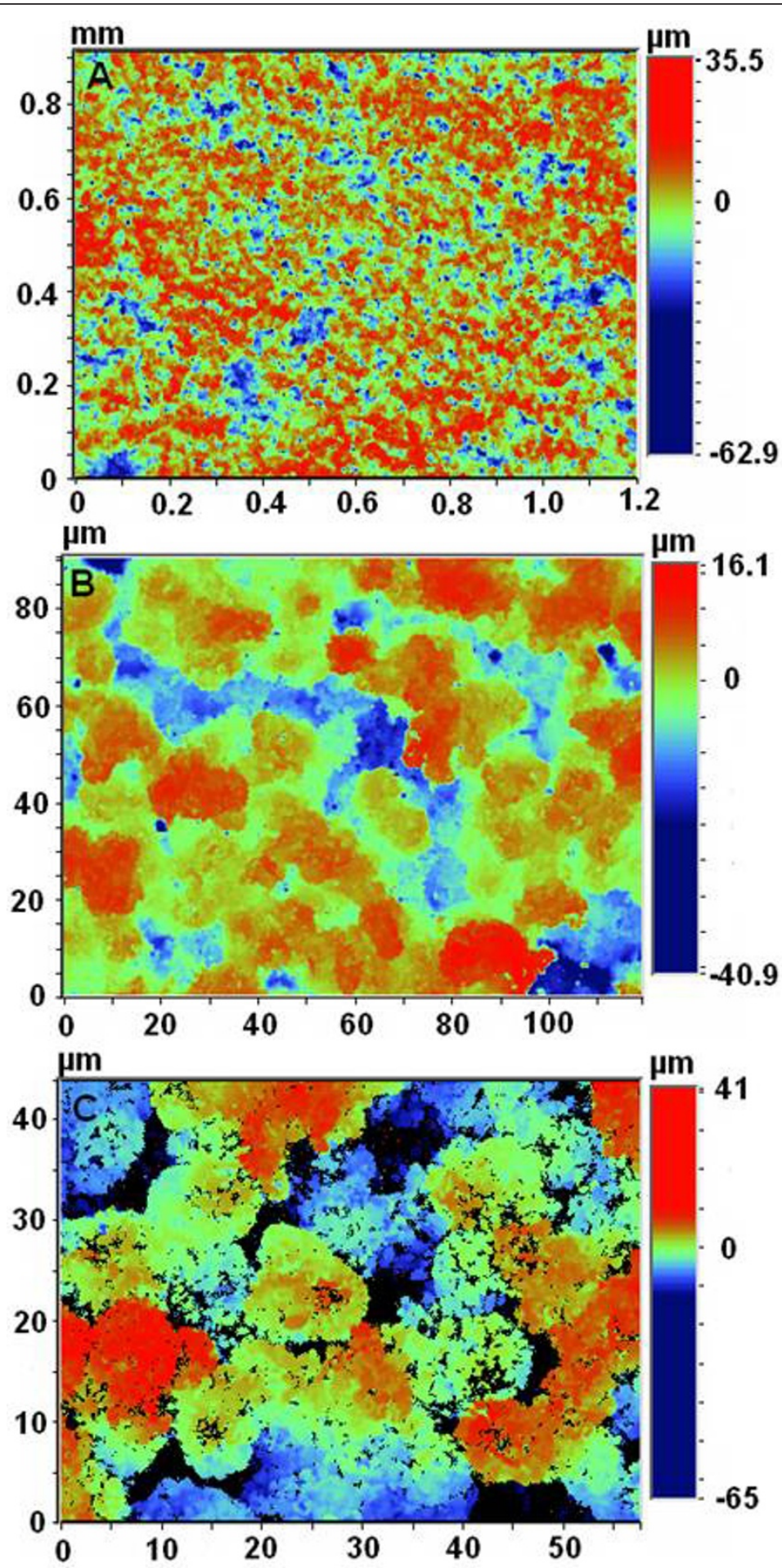

Figure 3 Optical profiler images of the rough PLLA surface. $a, b$ and $c$ are images taken with different magnifications.

shear forces (Verran and Boyd 2001; Whitehead and Verran 2006). Moreover, the extracellular matrix formed by P. aeruginosa cells on the $\mathrm{SH}$ material might also had a protective effect during the removal assays, due to its crucial role in maintaining structural integrity of $P$. aeruginosa biofilms (Chen and Stewart 2002).

In conclusion, this work showed that both PLLA surfaces tested are able to be colonized by bacterial cells, 

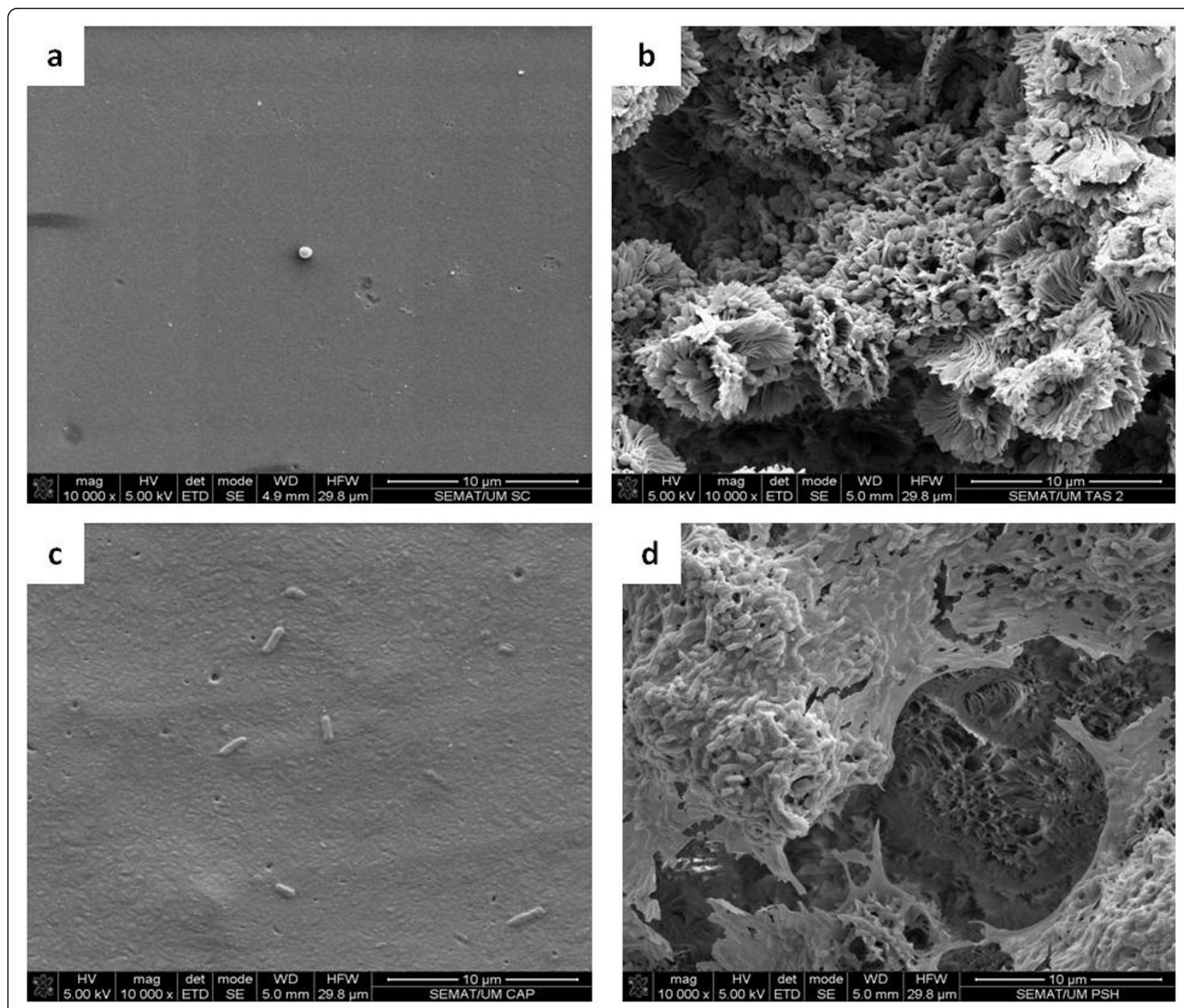

Figure 4 SEM images showing S. aureus colonization of (a) H PLLA surface and (b) SH PLLA surface; and P. aeruginosa colonization of (c) H PLLA surface and (d) SH PLLA surface.

regardless of their Gram-type and morphology. Nevertheless, a further analysis comparing the results obtained with both surfaces revealed that SH PLLA supported a higher amount of $S$. aureus cells, enabled biofilm formation by $P$. aeruginosa cells, and also suffered less bacteria removal when compared to the $\mathrm{H}$ surface. Therefore, it can be said that SH surfaces are not suitable for biomedical applications with antimicrobial properties. Conversely, this work introduces a possible application of PLLA-based superhydrophobic materials as bacterial colonization substrata with potential to be used as carriers for biomass immobilization in bio-reactors. Nevertheless, these studies are yet preliminary, since a higher number of strains need to be tested in order to address the intra-species variability in terms of surface characteristics and their consequent interaction with these surfaces. Likewise, a wider range of bacterial species, as well as other microorganisms with biotechnological potential, such as yeasts, and experimental conditions (culture media, temperature, incubation period, shear force, etc), need to be studied to confirm the conclusions presented here, and to clarify the observed high potential of using such modified surfaces as microbial colonization substrata in biotechnological processes.

\section{Acknowledgements}

Cláudia Sousa and Diana Rodrigues acknowledge the financial support of Portuguese Foundation for Science and Technology (FCT) through the grants SFRH/BPD/47693/2008 and SFRH/BPD/72632/2010, respectively. The authors are very grateful to Dr. Edith Ariza for her technical assistance in the SEM studies. 


\section{Author details}

${ }^{1}$ Institute for Biotechnology and Bioengineering, Centre of Biological Engineering, University of Minho, Campus de Gualtar, 4710-057 Braga, Portugal ${ }^{2} 3$ Bs Research Group - Biomaterials, Biodegradables and Biomimetrics, AvePark, Zona Industrial da Gandra, S. Cláudio do Barco, 4860909 Caldas das Taipas, Guimarâeas, Portugal ${ }^{3}$ ICVS/3B's - PT Government Associate Laboratory, Braga/Guimarâeas, Portugal

\section{Competing interests}

The authors declare that they have no competing interests.

Received: 19 August 2011 Accepted: 22 October 2011

Published: 22 October 2011

\section{References}

Ahn IS, Lee CH (2003) Kinetic studies of attachment and detachment of microbial cells from soil. Environ Technol 24:411-418. doi:10.1080/ 09593330309385575.

Ajayi BO, Otajevwo FD, Kio FE (2010) Adhesive capabilities of Staphylococcus aureus and Pseudomonas aeruginosa isolated from tears of HIV/AIDS patients to soft contact lenses. http://www.articlesbase.com/diseases-and-conditionsarticles/adhesive-capabilities-of-staphylococcus-aureus-and-pseudomonasaeruginosa-isolated-from-tears-of-hivaids-patients-to-soft-contact-lenses3854426.html

Alves NM, Shi J, Oramas E, Santos JL, Tomás H, Mano JF (2009) Bioinspired superhydrophobic poly(L-lactic acid) surfaces control bone marrow derived cells adhesion and proliferation. J Biomed Mater Res A 91A:480-488. doi:10.1002/jbm.a.32210.

Barthlott W, Neinhuis C (1997) Purity of the sacred lotus, or escape from contamination in biological surfaces. Planta 202:1-8. doi:10.1007/ s004250050096.

Bhushan B, Jung YC (2006) Micro- and nanoscale characterization of hydrophobic and hydrophilic leaf surfaces. Nanotechnology 17:2758-2772. doi:10.1088/0957-4484/17/11/008.

Bico J, Marzolin C, Quere D (1999) Pearl drops. Europhys Lett 47:220-226. doi:10.1209/epl/i1999-00548-y.

Callies M, Quéré D (2005) On water repellency. Soft Matter 1:55-61. doi:10.1039/ b501657f.

Camesano TA, Logan B (2000) Probing bacterial electrosteric interactions using atomic force microscopy. Environ Sci Technol 34:3354-3362. doi:10.1021/ es9913176.

Chen X, Stewart PS (2002) Role of electrostatic interactions in cohesion of bacterial biofilms. Appl Microbiol Biotechnol 59:718-722. doi:10.1007/s00253002-1044-2.

Donlan RM, Costerton JW (2002) Biofilms: survival mechanisms of clinically relevant microorganisms. Clin Microbiol Rev 15:167-93. doi:10.1128/ CMR.15.2.167-193.2002.

Drenkard E (2003) Antimicrobial resistance of Pseudomonas aeruginosa biofilms. Microbes Infect 5:1213-1219. doi:10.1016/j.micinf.2003.08.009.

Dunne WM (2002) Bacterial adhesion: seen any good biofilms lately? Clin Microbiol Rev 15:155-166. doi:10.1128/CMR.15.2.155-166.2002.

Edwards KJ, Rutenberg AD (2001) Microbial response to surface microtopography: the role of metabolism in localized mineral dissolution. Chem Geol 180:19-32. doi:10.1016/S0009-2541(01)00303-5.

Erbil HY, Demirel AL, Avci Y, Mert O (2003) Transformation of a simple plastic into a superhydrophobic surface. Science 299:1377-1380. doi:10.1126/ science. 1078365.

Fletcher El, Fleiszig SMJ, Brannan NA (1993) Lipopolysaccharide in adherence of Pseudomonas aeruginosa to the cornea and contact lenses. Invest Ophthalmol Vis Sci 34:1930-1936

Forberg C, Haggstrom L (1985) Control of cell adhesion and activity during continuous production of acetone and butanol with adsorbed cells. Enz Microbial Technol 7:230-234. doi:10.1016/S0141-0229(85)80008-9.

Frim JA (2008) Superhydrophobicity and superhydrophilicity: how we can mimic nature'sown"nanotechnology". http://www.nsec.ohio-state.edu/ teacher workshop/Superhydrophobicity.pdf

Gannon JT, Manilal VB, Alexander M (1991) Relationship between cell surface properties and transport of bacteria through soil. Appl Environ Microbiol 57:190-193
Genzer J, Efimenko K (2000) Creating long-lived superhydrophobic polymer surfaces through mechanically assembled monolayers. Science 290:2130-2133. doi:10.1126/science.290.5499.2130.

Nakajima A, Abe K, Hashimoto K, Watanabe T (2000) Preparation of hard superhydrophobic films with visible light transmission. Thin Solid Films 376:140-143. doi:10.1016/50040-6090(00)01417-6.

Nakajima A, Fujishima A, Hashimoto K, Watanabe T (1999) Preparation of transparent superhydrophobic boehmite and silica films by sublimation of aluminum acetylacetonate. Adv Mater 11:1365-1368. doi:10.1002/(SICI)15214095(199911)11:163.0.CO;2-F

Nakajima A, Hashimoto K, Watanabe T (2001) Recent studies on superhydrophobic films. Monatsh Chem 132:31-41 http://www.springerlink.com/ content/350tf9pgekt8qh8d/fulltext.pdf. doi:10.1007/s007060170142.

Oliveira NM, Neto Al, Song W, Mano JF (2010) Two-dimensional open microfluidic devices by tuning the wettability on patterned superhydrophobic polymeric surface. Appl Phys Express 3. Article Number: 085205. doi:10.1143/APEX.3.085205

Onda T, Shibuichi S, Satoh N, Tsujii K (1996) Super-water-repellent fractal surfaces. Langmuir 12:2125-2127. doi:10.1021/la9504180.

Parkin IP, Palgrave RG (2005) Self-cleaning coatings. J Mater Chem 15:1689-1695. doi:10.1039/b412803f.

Qureshi N, Maddox IS (1987) Continuous solvent production from whey permeate using cells of Clostridium acetobutylicum immobilized by adsorption onto bonechar. Enz Microbial Technol 9:668-671. doi:10.1016/ 0141-0229(87)90125-6.

Rocchetta HL, Burrows LL, Lam JS (1999) Genetics of O-Antigen biosynthesis in Pseudomonas aeruginosa. Microbiol Mol Biol Rev 63:523-553

Sanin SL, Sanin FD, Bryers JD (2003) Effect of starvation on the adhesive properties of xenobiotic degrading bacteria. Process Biochem 38:909-914. doi:10.1016/S0032-9592(02)00173-5.

Shi J, Alves NM, Mano JF (2008) Towards bioinspired superhydrophobic poly(Llactic acid) surfaces using phase inversion-based methods. Bioinspir Biomim 3 http://3bs.expertissues.org/download.php?file=303\&type=4\&doc=pubs Article Number: 034003

Shirtcliffe NJ, Hale G, Newton MI, Perry CC (2003) Intrinsically superhydrophobic organosilica sol-gel foams. Langmuir 19:5626-5631. doi:10.1021/la034204f.

Song W, Veiga DD, Custódio CA, Mano JF (2009) Bioinspired degradable substrates with extreme wettability properties. Adv Mater 21:1830-1834. doi:10.1002/adma.200803680

Speranza G, Gottardi G, Pederzolli C, Lunelli L, Canteri R, Pasquardini L, Carli E, Lui A, Maniglio D, Brugnara M, Anderle M (2004) Role of chemical interactions in bacterial adhesion to polymer surfaces. Biomaterials 25:2029-2037. doi:10.1016/j.biomaterials.2003.08.061.

Sun TL, Feng L, Gao XF, Jiang L (2005) Bioinspired surfaces with special wettability. Acc Chem Res 38:644-652. doi:10.1021/ar040224c.

Tadanaga K, Morinaga J, Matsuda A, Minami T (2000) Superhydrophobicsuperhydrophilic micropatterning on flowerlike alumina coating film by the sol-gel method. Chem Mater 12:590-592. doi:10.1021/cm990643h.

Teare DOH, Spanos CG, Ridley P, Kinmond EJ, Roucoules V, Badyal JPS, Brewer SA, Coulson S, Willis C (2002) Pulsed plasma deposition of superhydrophobic nanospheres. Chem Mater 14:4566-4571. doi:10.1021/ cm011600f.

Thuruthyil SJ, Zhu H, Willcox MD (2001) Serotype and adhesion of Pseudomonas aeruginosa isolated from contact lens wearers. Clin Experiment Opthalmo 29:147-149. doi:10.1046/j.1442-9071.2001.00396.x.

Tsuji H, Ikada Y (1998) Blends of aliphatic polyesters II. hydrolysis of solution-cast blends from poly (L-lactide) and poly (E-caprolactone) in phosphate-buffered solution. J Appl Polym Sci 67:405-415. doi:10.1002/(SICI)1097-4628(19980118) 67:33.0.CO;2-Q.

Tyagi RD, Ghose TK (1982) Studies on immobilized Saccharomyces cerevisiae I. Analysis of continuous rapid ethanol fermentation in immobilized cell reactor. Biotechnol Bioeng 24:781-795. doi:10.1002/bit.260240403.

Urayama H, Kanamori T, Kimura Y (2002) Properties and biodegradability of polymer blends of poly (L-lactide) with different optical purity of the lactate units. Macromol Mater Eng 287:116-121. doi:10.1002/1439-2054(20020201) 287:23.0.CO;2-Z

Verran J, Boyd RD (2001) The relationship between substratum surface roughness and microbiological and organic soiling: A review. Biofouling 17:59-71. doi:10.1080/08927010109378465. 
Wang Y, Liu Z, Han B, Sun Z, Zhang J, Sun D (2005) Phase-separation-induced micropatterned polymer surfaces and their applications. Adv Funct Mater 15:655-663. doi:10.1002/adfm.200400201.

Whitehead KA, Verran J (2006) The effect of surface topography on the retention of microorganisms. Food Bioprod Process 84:253-259. doi:10.1205/fbp06035.

Woodward I, Schofield WCE, Roucoules V, Badyal JPS (2003) Super-hydrophobic surfaces produced by plasma fluorination of polybutadiene films. Langmuir 19:3432-3438. doi:10.1021/la020427e.

Xie Q, Xu J, Feng L, Jiang L, W Tang, Luo X, Han CC (2004) Facile creation of a super-amphiphobic coating surface with bionic microstructure. Adv Mater 16:302-305. doi:10.1002/adma.200306281.

Zmantar T, Bettaieb F, Chaieb K, Ezzili B, Mora-Ponsonnet L, Othmane A, Jaffrézic N, Bakhrouf A (2011) Atomic force microscopy and hydrodynamic characterization of the adhesion of staphylococcus aureus to hydrophilic and hydrophobic substrata at different pH values. World J Microbiol Biotechnol 27:887-896. doi:10.1007/s11274-010-0531-3.

doi:10.1186/2191-0855-1-34

Cite this article as: Sousa et al.: Superhydrophobic poly(L-lactic acid) surface as potential bacterial colonization substrate. AMB Express 2011 $1: 34$.

\section{Submit your manuscript to a SpringerOpen ${ }^{\mathcal{O}}$ journal and benefit from:}

- Convenient online submission

- Rigorous peer review

- Immediate publication on acceptance

- Open access: articles freely available online

- High visibility within the field

- Retaining the copyright to your article

Submit your next manuscript at $\gg$ springeropen.com 